Diabetologia 8, 334-341(1972)

(C) by Springer-Verlag 1972

\title{
Ultrastructural and Biometric Action of Insulin on Foetal Rat Pancreas
}

\author{
H. Perrier, R. Jacquot \\ Laboratoire de Physiologie animale et Centre de Biologie et Biochimie du Développement. Faculté des Sciences, Reims \\ (France)
}

Received: February 4, 1972, accepted: June 20, 1972

Summary. In order to study the possible repercussions of an exogenous insulin overload on the electron microscopic aspect of their pancreas, rat foetuses were given one insulin (2 I.U.) injection at day 19 of gestation, two at day 20 and were sacrificed at day 21 . Their pancreases were compared to those of non injected littermate controls. - As far as the exocrine portion of the pancreas was concerned, the insulin overload resulted in some ultrastructural changes: enhanced polarity of the cells, large zymogen granules more often encountered, microvilli more numerous. - The mere examination of the electron micrographs of the endocrine pancreas suggested that exogenous insulin modifies the number, the dispersion and the size of the secretory granules. Therefore a biometric approach was used in order to obtain an objective evaluation of the results. The biometric method is described and discussed. - 1. At the level of the A cells, insulin overload increased the number of those secretory vesicles which are fused with the cell membrane (no other major modification in the ultrastructural aspect of the A cells was noted). These observations suggest that the pancreas of insulin treated foetuses releases an enhanced amount of glucagon. -2 . At the level of the B cells, insulin overload increased the number of those vesicles which are very close to the cell membrane, but decreased the number of the vesicles which are actually fused with the plasma membrane. It seems therefore that one step of the emiocytosis process (fusion between vesicle and plasma mem. branes) is partially inhibited by insulin treatment: as a counterpart a slight increase in the number of secretory vesicles occurs throughout the cytoplasm and a marked increase in the close vecinity of the cell membrane. $\mathrm{Nu}$ merous B cells belonging to insulin treated foetuses showed an abnormally high density of immature granules, some of them being very large, suggesting that some steps in the biosynthetic process of insulin might have been affected as well; but the ultrastructure of the cellular organelles classically involved in such a process is un affected. - To conclude it seems that, in vivo, an overload in exogenous insulin affects both the secretion and the biosynthesis of endogenous insulin by the rat foetal pancreas.

Etude ultrastructurale el biométrique de l'action de l'insuline sur le pancréas foetal de rat.

Résumé. Dans le but d'étudier l'influence éventuelle d'une surcharge en insuline exogène sur l'aspect en microscopie électronique de leur pancréas, des foetus ont reçu une injection à 19 jours et deux injections à 20 jours de 2 U.I. d'insuline et ont été sacrifiés à 21 jours. Leur pancréas fut comparé à celui des foetus témoins. L'injection d'insuline a entraîné, au niveau du pancréas exoerine, quelques changements ultrastructuraux : polarité des cellules plus visible, grains de sécrétion plus fréquemment de grande taille, microvilli plus nombreux. - Le simple examen des micrographies du pancréas endocrine ayant révélé que l'insuline exogène modifie la richesse, la répartition et la taille du matériel sécrétoire, une méthode biométrique fut mise au point dans le but de rendre les résultats aussi objectifs que possible. Cette méthode a été décrite et discutée. - 1. Au niveau des cellules $A$, la surcharge en insuline augmente le nombre de granules sécrétoires accolés à la membrane cytoplasmique, (sans entraîner par ailleurs de modifications ultrastructurales appréciables), cette observation suggère que le pancréas des foetus traités sécrète davantage de glucagon. - 2 . Au niveau des cellules $B$, la surcharge en insuline augmente le nombre de granules situés au voisinage immédiat de la membrane cytoplasmique, tout en diminuant le nombre de ces granules réellement accolés à cette membrane; tout se passe comme si une des étapes de l'émiocytose (accolement granules - membrane cytoplasmique) était partiellement inhibée. Ce blocage de la libération d'insuline pourrait expliquer le léger accroissement en matériel sécrétoire observé dans l'ensemble du cytoplasme des cellules $\mathrm{B}$ des animaux traités. - Par ailleurs de nombreuses cellules B des foetus injectés présentent un nombre anormalement élevé de granules sécrétoires immatures, ce qui suggère que certaines étapes de la biosynthèse de l'insuline sont touchées. Mais aucune modification n'est visible dans l'aspect ultrastructural des organites cellulaires classiquement impliqués dans cette biosynthèse. - En conclusion, il semble que in vivo, une surcharge en insuline exogène affecte la biosynthèse et la sécrétion de l'insuline endogène.

Ultrastrukturelle und biometrische Untersuchung über die Wirkung von Insulin auf das fötale Rattenpankreas.

Zusammenfassung. In der Absicht, den Einfluß einer exogenen Insulinüberbelastung auf das elektronenmikroskopische Bild des Pankreas zu studieren, wurden fötalen Ratten am 19. Tag der Gestation eine Injektion und am 20. Tag zwei Injektionen von 2 IE Insulin gegeben. Die Tiere wurden am 21. Tag getötet und ihr Pankreas mit demjenigen der nicht behandelten Wurfgeschwister verglichen. Im exokrinen Pankreas bewirkte die Injektion von Insulin einige ultrastrukturelle Veränderungen: Die Polarität der Zellen ist besșer sichtbar, die Sekretkörnchen sind häufig größer und die Mikrovilli zahlreicher. - Die einfache Betrachtung der Mikrophotographien des endokrinen Pankreas zeigte, daß eine exogene Insulinüberladung die Anzahl, die Verteilung und die Größe der Sekretkörnchen verändert. Deshalb wurde eine biometrische Methode ausgearbeitet, um die Ergebnisse so objektiv wie möglich zu gestalten. Die biometrische Methode wird hier beschrieben und diskutiert. - 1. In den A-Zellen erhöht die Insulinüberladung die Anzahl der mit der Zellmembran verschmolzenen Sekretkörnchen. (Andere größere ultrastrukturelle Veränderung in den A-Zellen waren nicht festzustellen). Diese Beobachtung deutet darauf hin, daß das Pankreas behandelter fötaler Ratten mehr Glukagon ausschüttet. - 2. In den B-Zellen erhöht die Insulinüberladung die Anzahl der Körnchen in der unmittelbaren Nachbarschaft der Zellmembran, während gleichzeitig die Anzahl der mit der Zellmembran wirklich verschmolzenen Körnchen vermindert ist. Dies erweckt den Anschein, als ob eine Phase der Emiozytose (Verschmelzen, der Körner mit der Zellmembran) durch 
die Insulinbehandlung gehemmt sei: im Gegensatz dazu steht die geringe Vermehrung der Sekretkörnchen im gesamten Cytoplasma und die bedeutende Vermehrung in der unmittelbaren Nachbarschaft der Zellmembran. Zahlreiche B-Zellen der behandelten fötalen Ratten zeigen eine ungewöhnlich hohe Dichte von unreifen. Sekretkörn- chen, von denen einige sehr groß sind, was darauf hindeutet, daß bestimmte Phasen der Biosynthese des Insulins berührt worden sein können. Aber der Aspekt der Ultrastruktur der zellulären Organellen, die in klassischer Weise an der Biosynthese beteiligt sind, ist unverändert.
Several authors have tested whether insulin can exert a control on its own secretion or (and) biosynthesis. Generally, following in vivo treatment with insulin, they observe, in the adult animal, a diminution in the number of granules per B cell $[1,24,25,26]$, or a decrease in insulin content of the pancreas $[2,4,25,29$, $36]$. These changes are often attributed to alterations believe that it is mediated by the induced hypoglycaemia. Similarly, there is some controversy about the effects of exogenous insulin upon pancreas reactivity to a glucose load $[14,1,4,25]$.

In vitro studies on perfused pancreas, minced pancreas or isolated islets might seem more proper to give a clear cut answer since they allow the glucose

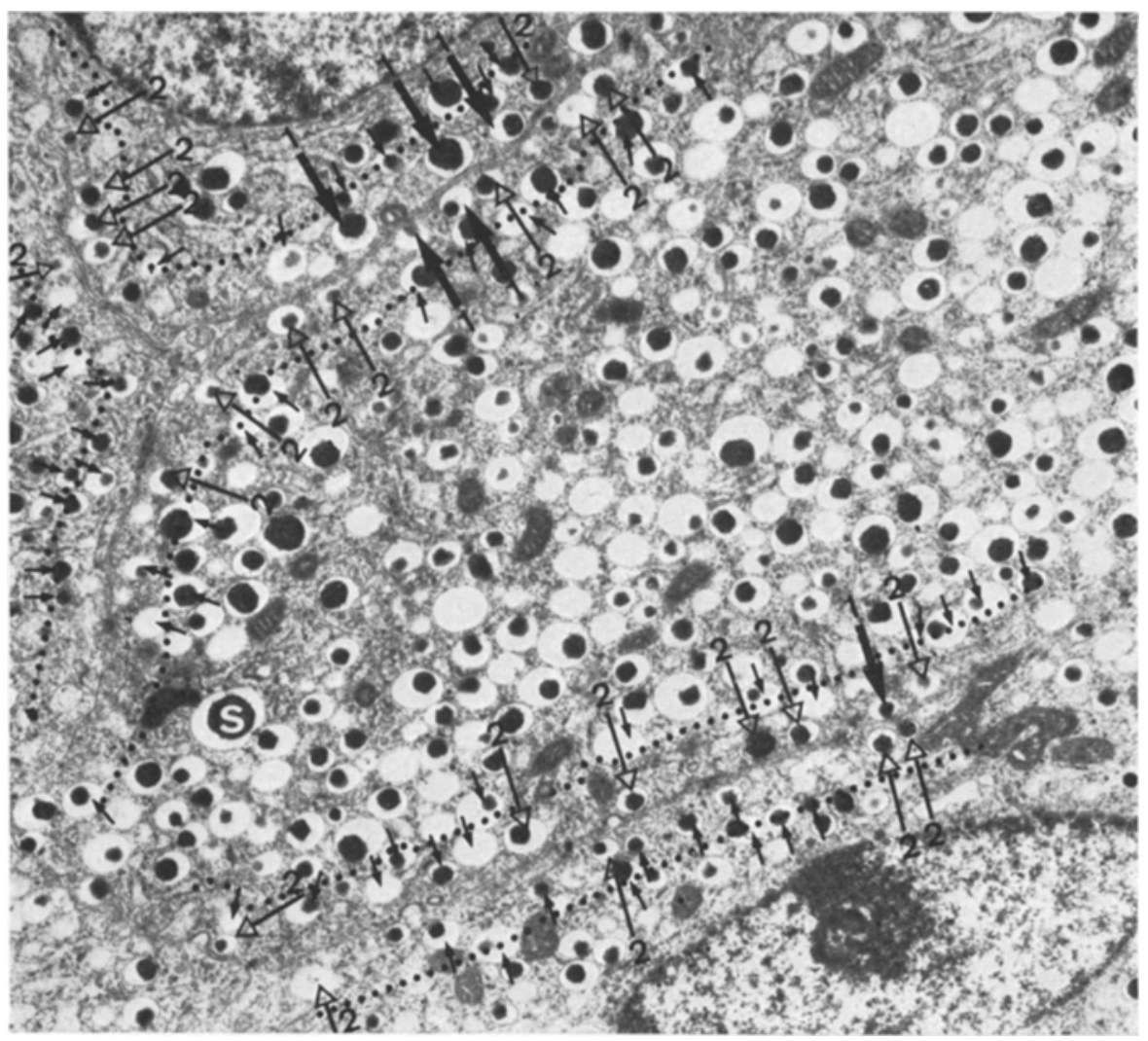

Fig. 1. Illustration of the biometric method. Portion of a reconstructed map in a treated foetus, showing the different groups of vesicles inside the peripheral strip (ef. text) $(\times 8400)$

$$
\begin{array}{cl}
\ldots . . . & \text { inner limit of the strip } \\
\mathbf{1} \rightarrow & \text { secretory vesicles belonging to group I } \\
\vec{\longrightarrow} & \text { secretory vesicles belonging to group II } \\
\overrightarrow{\mathrm{S}} & \text { secretory vesicles belonging to group III } \\
& \text { large secretory granule. }
\end{array}
$$

in the processes of insulin biosynthesis $[1,2,26]$; Malaisse et al. [29] and Logothetopoulos et al. [24] believe however that both biosynthetic and secretory processes are affected.

Concerning the mode of action of insulin in such a short feed-back control, Hausberger et al [14] consider it to be a direct one, whereas Batts [1], Chu etal. [4] level to be maintained constant while changing insulin levels. Nevertheless a rather wide discrepancy exists between the results so far obtained. According to several authors $[7,9,12,13,15,16,27,35,37]$ insulin inhibits in vitro insulin secretion, some others [11,28] think it does not. Previous in vivo chronic treatment with insulin diminishes the in vitro insulin secretion of 
the pancreas $[29,36]$, but the insulin secretory performances of the healthy part of a pancreas are not altered by the presence of an insulin secreting tumor [5].

In line with these inconclusive results, very few observations were made concerning the action of insulin on the ultrastructure of A or B cells, and practically none concerning the foetus. The present paper describes some effects of insulin overload in the rat foetus.

\section{Methods}

Wistar rats (C.F. strain, C.N.R.S.) were used. Day 0 (first day) of pregnancy was determined by the presence of spermatozoa in the vagina.
In order to compare the total wealth of secretory granules in $B$ cells, 2 sets of micrographs were prepared, one for treated, the other for control foetuses. These were submitted to several independant observers who had to say whether they saw any difference between the sets (they knew nothing about the origin of the micrographs).

In order to evaluate modifications in insulin secretory processes, we compared, between control and treated foetuses, the number of secretory vesicles at the periphery of the $B$ cells, their dispersion, and the frequency of their fusion with the plasma membrane. Thus on electron micrographs at the same $(\times 8400)$ enlargement, which had been assembled in "maps" covering large portions of the islets, we defined at the periphery of the B cells a strip 1,5 times broader than the mean size of the vesicles. This mean size had been determined by measuring the larger diameter of 300 randomized vesicles both in control and treated foetuses. The strip was delimited by drawing a line parallel to the plasma membrane (at $6 \mathrm{~mm}$ from it on a $\times 8400$

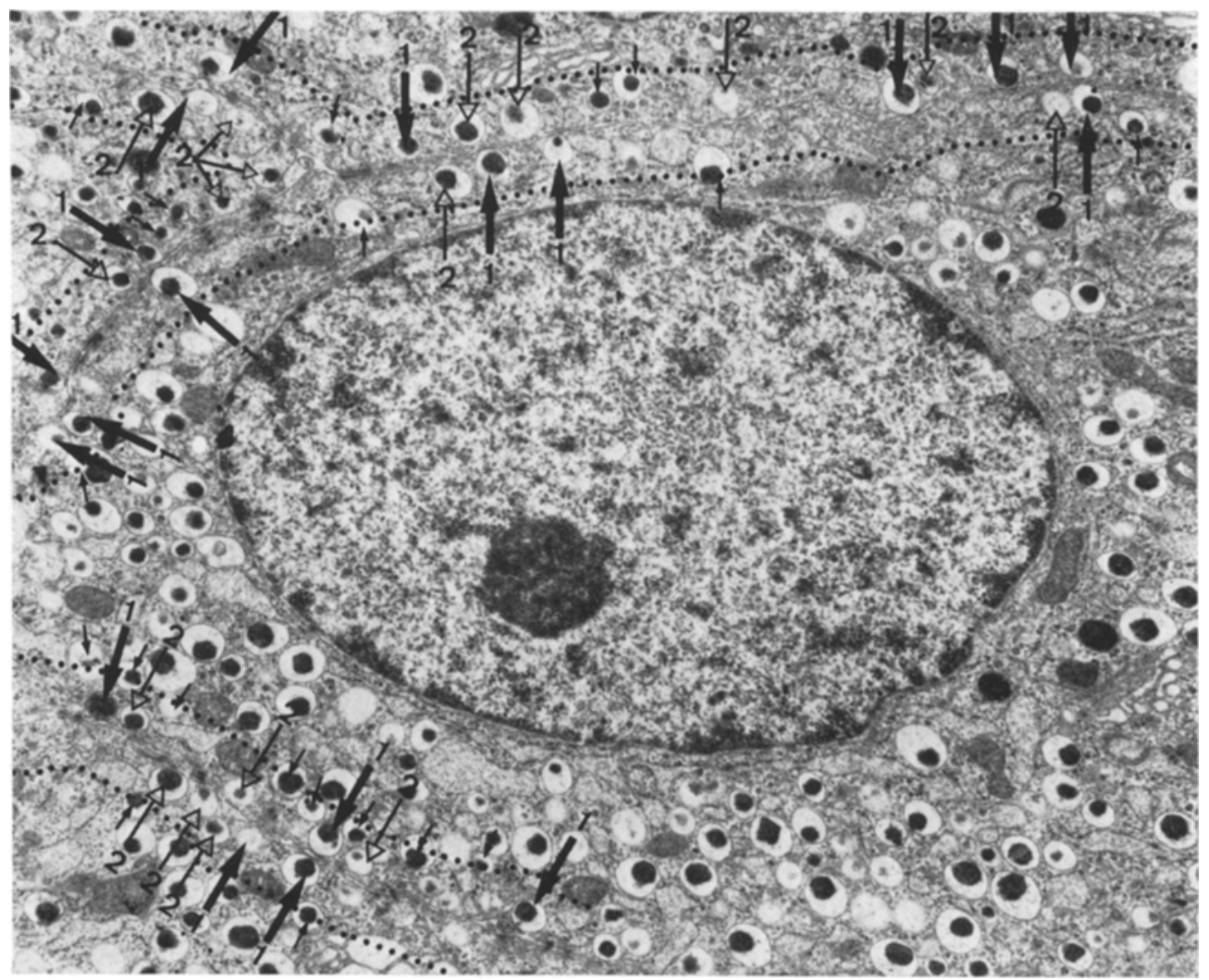

Fig. 2. Control foetus (for legend confer Fig. 1)

5 foetuses belonging to 3 different litters were given insulin ("treated" foetuses). After laparotomy of their mother, they received, through the uterine wall, under the skin of the back, 3 injections of 2 I.U. protaminezinc-insulin: one at day 19 , two at day 20 of gestation. Their pancreas and the pancreas of their control littermates were collected at day 21 of gestation, fixed for 5 to $10 \mathrm{~min}$ with glutaraldehyde, post-fixed for 1 hour in osmic acid, and embedded in araldite. The ultra-thin sections were contrasted with the uranyl acetate - lead citrate technique and observed in a Hitachi H.S. 8 electron microscope. enlargement, Fig. 1 and 2). Vesicles inside the strip were classified in three groups:

Group I: vesicles "fused" with the plasma membrane

Group II: vesicles separated from the membrane by a distance equal or less than $1 / 4$ of the mean vesicular size ("almost fused" vesicles).

Group III: the other vesicles of the strip.

The assignation of the vesicles to their group was performed on randomized photos by one of us, who did not know the origin of the micrographs, and within a few successive days (in order to avoid a shift in subjective criteria). Then the total number of vesicles of each group 
was expressed per arbitrary unit of membrane length (the total lengths of the eytoplasmic membranes covering the studied strips had been measured with a curvimeter).

It seemed also interesting to compare, between, control and treated foetuses, the frequency of occurrence of large vesicles (or granules). This was done by counting the number of vesicles (or granules) larger than a given size (see below) per arbitrary unit of cytoplasmic surface; eytoplasmic surfaces were measured by weighing their copies on homogenous paper.

For A cells, the number of "fused" vesicles per membrane length has been evaluated as previously described.

In the exocrine part of the pancreas the number, per cytoplasmic surface unit, of zymogen granules larger than a given size (see below) was evaluated as described for $B$ cells. frequency of their fusion with the plasma membrane was smaller (Fig. 1 and 2). The biometric study confirmed this finding. Since the results obtained by this method were variable from cell to cell, we used large reconstructed maps (cf. methods). In a given foetus, membrane lengths and number of vesicles of each group were then pooled without reference to any given cell, and the frequency of vesicles per arbitrary unit length of membrane was calculated from these pooled data. If more than $20 \mathrm{~B}$ cells were involved in such a determination, the reproducibility for a given foetus was very good. Table 1 gives an example of the results obtained from 3 treated foetuses belonging to 3 differ-

Table 1. Three treated foetuses belonging to three different litters

\begin{tabular}{|c|c|c|c|c|}
\hline \multicolumn{2}{|c|}{$\begin{array}{l}\text { Groups of } \\
\text { vesicles }\end{array}$} & \multirow{2}{*}{$\begin{array}{l}\text { Foetus A } \\
\begin{array}{c}251 \\
10.1\end{array}\end{array}$} & \multirow{2}{*}{$\begin{array}{c}\text { Foetus B } \\
190 \\
1.0 .0\end{array}$} & \multirow{2}{*}{$\begin{array}{c}\text { Foetus C } \\
213 \\
8.7\end{array}$} \\
\hline $\mathrm{I}$ & $\begin{array}{l}\text { Nbr. ves. / U. memb. lengtha } \\
\text { Percentages of IVb }\end{array}$ & & & \\
\hline II & $\begin{array}{l}\text { Nbr. ves. / U. memb. length } \\
\text { Percentages of } I^{\mathrm{b}} \mathrm{b}\end{array}$ & $\begin{array}{l}957 \\
38.4\end{array}$ & $\begin{array}{l}704 \\
36.8\end{array}$ & $\begin{array}{l}951 \\
39.0\end{array}$ \\
\hline III & $\begin{array}{l}\text { Nbr. ves. / U. memb. length } \\
\text { Percentages of } \mathrm{IV}^{\mathrm{b}}\end{array}$ & $\begin{array}{l}1282 \\
51.5\end{array}$ & $\begin{array}{l}1016 \\
53.2\end{array}$ & $\begin{array}{r}1276 \\
52.3\end{array}$ \\
\hline IV & $\begin{array}{l}\text { Nbr. ves. / U. memb. lengtha } \\
\text { Percentages of } \mathrm{IV}^{\mathrm{b}}\end{array}$ & $\begin{array}{l}2489 \\
(100)\end{array}$ & $\begin{array}{l}1911 \\
(100)\end{array}$ & $\begin{array}{l}2441 \\
(100)\end{array}$ \\
\hline \multicolumn{2}{|c|}{$\begin{array}{l}\text { Nbr. of cells studied } \\
\text { Nbr. of vesicles numbered }\end{array}$} & $\begin{array}{r}31 \\
1478\end{array}$ & $\begin{array}{r}35 \\
1324\end{array}$ & $\begin{array}{r}21 \\
1029\end{array}$ \\
\hline
\end{tabular}

Table 2. Pooled data on control and treated foetuses (cf. text)

\begin{tabular}{|c|c|c|c|c|}
\hline $\begin{array}{l}\text { Groups of } \\
\text { vesicles }\end{array}$ & $\begin{array}{l}\text { Type of } \\
\text { foetuses }\end{array}$ & $\begin{array}{l}\text { Nbr. ves. } \\
\text { U. memb. } \\
\text { lengtha }\end{array}$ & Percentages ${ }^{b}$ & $\begin{array}{l}\text { Treated } \\
\text { Control }\end{array}$ \\
\hline I & $\begin{array}{l}\text { Treated } \\
\text { Control }\end{array}$ & $\begin{array}{l}217 \\
355\end{array}$ & $\begin{array}{r}9.7 \\
25.2\end{array}$ & 0.6 \\
\hline II & $\begin{array}{l}\text { Treated } \\
\text { Control }\end{array}$ & $\begin{array}{l}853 \\
375\end{array}$ & $\begin{array}{l}38.0 \\
26.5\end{array}$ & 2.3 \\
\hline III & $\begin{array}{l}\text { Treated } \\
\text { Control }\end{array}$ & $\begin{array}{r}1173 \\
682\end{array}$ & $\begin{array}{l}52.3 \\
48.3\end{array}$ & 1.7 \\
\hline$\underbrace{I V}_{(=I+I I+I I I)}$ & $\begin{array}{l}\text { Treated } \\
\text { Control }\end{array}$ & $\begin{array}{l}2243 \\
1411\end{array}$ & & 1.6 \\
\hline
\end{tabular}

a Number of vesicles per arbitrary length of cytoplasmic membrane

b Vesicles percentages of group IV of each I, II, III group

c Number of vesicles (per arbitrary length of membrane) in treated foetuses versus number of vesicles in control foetuses

\section{Results}

\section{$B$ Cells}

All the observers found the global wealth of secretory granules in $\mathrm{B}$ cells greater in treated than in control foetuses.

The frequency and dispersion of these vesicles at the periphery showed great variability inside a single cell and from cell to cell. Nevertheless, the mere visual observation of a sufficient number of micrographs gave the impression that the peripheral vesicles were more numerous in treated foetuses but that the ent litters and shows that the reproducibility between these foetuses was good. We have verified that the same conclusion holds for control foetuses, regardless of the litter. Therefore the final results, shown in Table 2, were obtained from all control and all the treated foetuses. In each experimental set, the lengths of plasma membrane utilized and the corresponding numbers of vesicles (of each group) were pooled, regardless of the foetus, and the frequencies per unit length of membrane calculated from the pooled data, which obviously cannot be treated statistically.

Table 2 shows that the number of vesicles at the 
periphery of $B$ cells (IV) is enhanced $(\times 1,6)$ by insulin treatment; nevertheless "fused" vesicles (group I) are less frequent and, as a counterpart, vesicles of group III and especially of group II ("almost fused") are more numerous $(\times 2,3)$.

Study of the micrographs suggests that the size of some mature granules and of their vesicles was enlarged after insulin treatment. Therefore 250 randomized whole B cells were studied in control and in treated foetuses. In treated foetuses, the number, per surface unit, of mature granules with a diameter greater (or equal) to $463 \mathrm{~nm}(2.5 \mathrm{~mm}$ on a $\times 5400$ enlargement)
Otherwise, the appearance of nucleus, ergastoplasm, golgi apparatus and mitochondria was not affected by insulin treatment.

\section{A Cells}

Their general ultrastructural appearance and the number and the size of their secretory granules were not modified in treated foetuses. But the frequency of fusion of these vesicles with the cell membrane was greater in treated foetuses, as shown by careful observation (Fig. 3 and 4 ) and as measured biometrically (3 times greater).

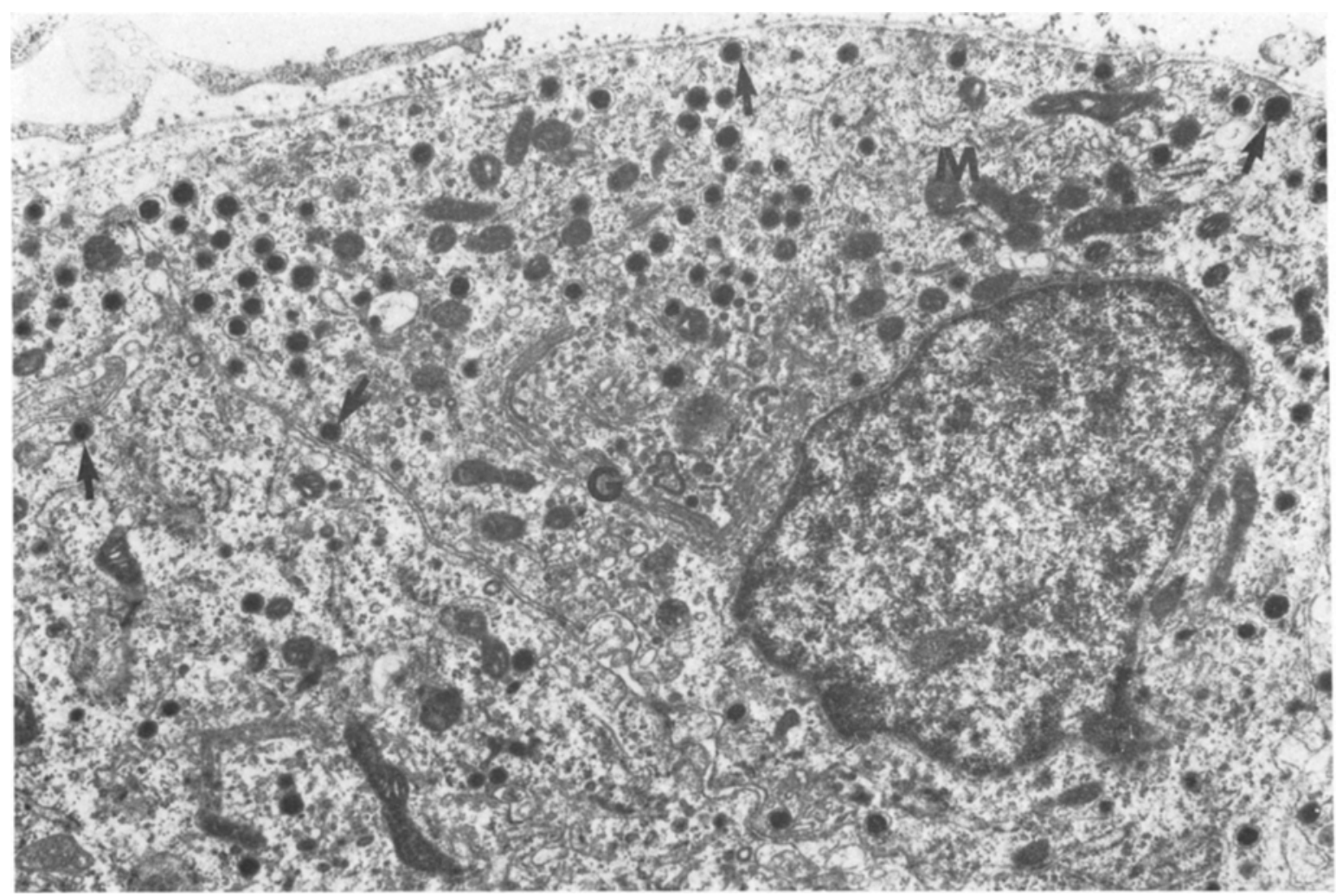

Fig. 3. Treated foetus. A cells. Few secretory vesicles fused with plasma membrane (arrows). G: golgi. M: mitochondria

was twice the value of control foetuses; accordingly the vesicles with a diameter between 926 and $1111 \mathrm{~nm}$ ( 5 and $6 \mathrm{~mm}$ on graphs) were three times more numerous, and with a diameter greater than $1111 \mathrm{~nm}, 27$ times more numerous.

After insulin treatment, some B cells contained an abnormally high number of immature granules (spherical, electron dense granules, separated from the vesicular membrane only by a narrow space, thus similar to A granules but larger). In the cellular populations used above for mature granules, immature granules with a size between 556 and $648 \mathrm{~nm}$ (3 and $3.5 \mathrm{~mm}$ on graphs) were 3 times more numerous per surface unit of cytoplasm in treated foetuses, and those larger than $648 \mathrm{~nm}, 7$ times more frequent.

\section{Exocrine Cells}

In treated foetuses, the exocrine pancreatic cells had a more obvious polarity and more numerous microvilli. Using 300 cells for each experimental group it was found that, per surface unit, zymogen granules with a diameter equal to or greater than $2143 \mathrm{~nm}$ (9 $\mathrm{mm}$ on a $\times 4200$ enlargement) were 4 times more numerous in treated foetuses.

\section{Discussion and Conclusion}

Before giving an interpretation of the results, a criticism of the methodology is necessary.

Each foetus received, over a period of roughly $48 \mathrm{~h}, 6 \mathrm{I}$.U. of insulin, a large amount indeed. We do 
not know the turnover rate of this hormone in the foetus, and we did not measure the foetal blood glucose levels: it appears that insulin barely affects blood glucose in foetal rats before day 21 (32). One might conceive that the observed effects were the result of the transfer of insulin to the mother and of the induced maternal hypoglycaemia. This seems unlikely, for such a transfer has never been demonstrated by other workers; should it happen, the pregnant rats that were operated on three times in less than $48 \mathrm{~h}$ (and therefore did not eat much) would have received $6 \mathrm{I}$. U. ( 1 foetus was not arbitrary, if one is interested in the secretion process. The way this dispersion was performed avoids any bias. In our opinion, the results are reproducible and worth analyzing.

\section{Exocrine Cells}

In the adult, insulin increases the production of pancreatic juice and its concentration in enzymes $[6$, $23,39]$. In the treated foetus the changes seen in exocrine cells (polarity, microvilli, size of granules) indicate that they react to the overload in insulin.

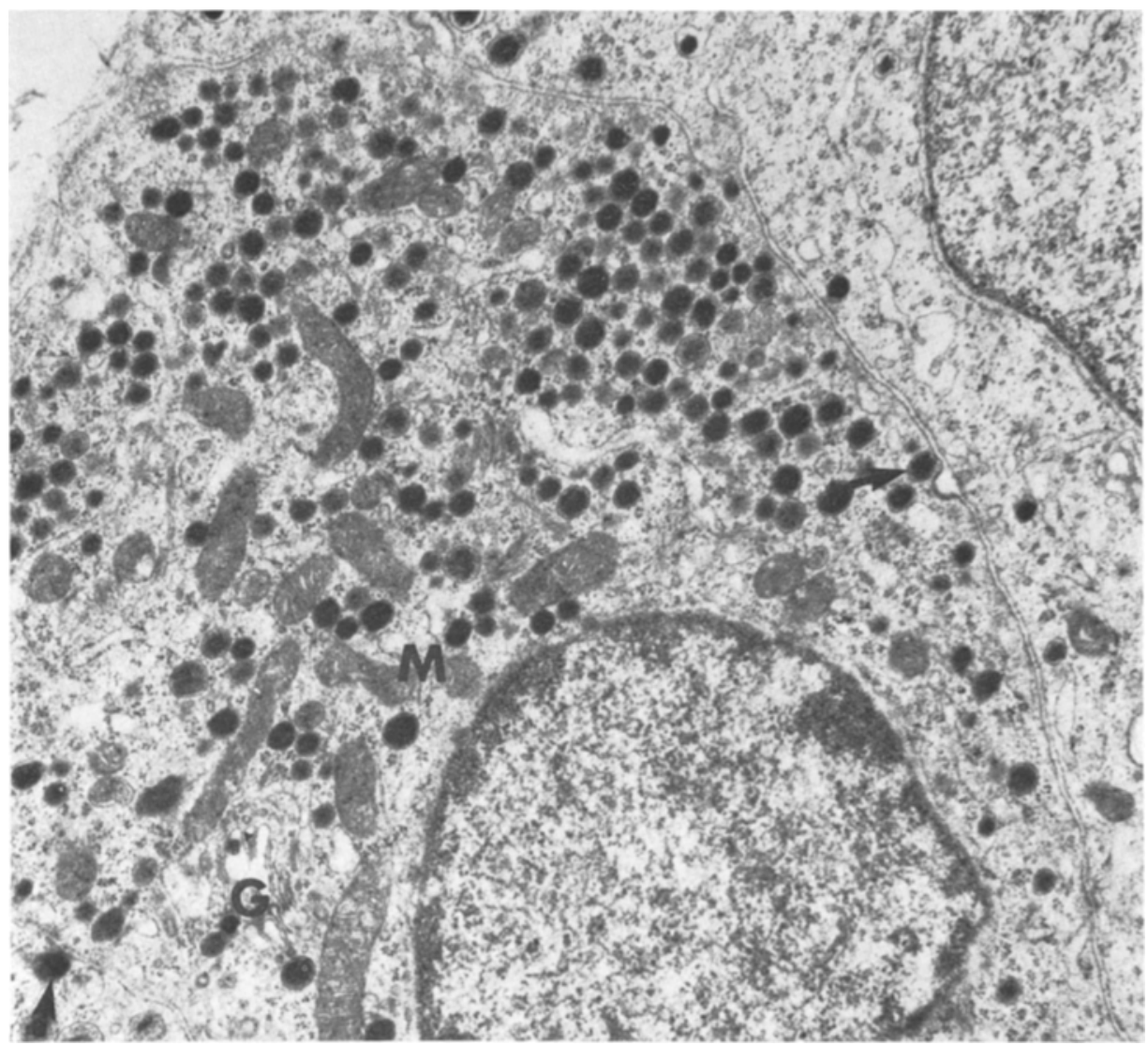

Fig. 4. Control foetus. A cells. Rare secretory vesicles fused with plasma membrane (arrows). G: golgi. M: mitochondria

injected) or 12 I.U. (2 foetuses injected) without showing any clinical sign of hypoglycaemia.

Another criticism deals with the validity of the results. At the ultrastructural level, it is rare that an experimental treatment produces changes so obvious that they can be seen at first glance; generally the observer makes his opinion after a long inspection of numerous micrographs. We tried to avoid a subjective evaluation by increasing the number of observers not informed of what they had to discover, and by using a biometric approach.

Concerning that biometric approach, the width of the strip around the B cells was arbitrary but the dispersion of the vesicles inside this strip into 3 groups

\section{A Cells}

In the adult, chronic insulin administration does not modify the structure $[1,21,24]$ or ultrastructure $[1,21]$ of the $A$ cells. Our results in the foetus are very similar: A cells from treated foetuses did not differ from those of normal foetuses of comparable age [31].

In the adult, chronic insulin administration induces no change in the number and distribution of secretory granules [1, 21]. In the foetus, if the total number of these granules is not affected, the frequency of fusion between vesicles and cell membrane is enhanced, a fact which suggests an enhanced secretion of glucagon, if emiocytosis is the secretory process [10]. 


\section{B Cells}

After 2 days of insulin treatment, foetal B cells present a small increase in the total number of their secretory vesicles: this is in good agreement with what is described in the adult following short term treatment with insulin $[1,20]$. Under chronic insulin administration, however, a diminution in the number of vesicles is observed in the adult $[1,20,24,25,26]$. We do not know if insulin affects the number of $B$ cells per pancreas and our results therefore cannot be compared with what is known in the adult concerning the fluctuations of insulin content after insulin treatment [2, $4,25,29]$.

The mode of dispersion of secretory vesicles at the periphery of the cells suggests, both in control and treated foetuses, a tendancy for accumulation just below the cell membrane: vesicles of groups I and II represent roughly 50 per cent of the total population while being found in only $1 / 6$ of the strip. It seems therefore that the limiting factor for vesicular discharge is fusion with the cell membrane rather than migration to the periphery. In treated foetuses, although more vesicles are found at the periphery, fewer are actually fused with the cell membrane and there is a marked accumulation just below this membrane ("almost fused"): if emiocytosis is the secretory process $[22,34]$, one may postulate that exogenous insulin reduces endogenous insulin secretion by inhibiting fusion between vesicles and cell membrane. Such a phenomenon might explain the increase in total number of granules in treated $\mathbf{B}$ cells as well as the relative frequency of large sized mature granules. In the adult, several authors have also suggested an inhibition (direct or indirect) of insulin on its own secretion $[9,12,13,14,15,27,29,35,36,37]$.

B cells of treated foetuses are sometimes rich in immature granules and some of these granules are very large. If the conversion of proinsulin to insulin takes place in developing granules $[18,38]$, our observations might suggest that exogenous insulin somehow interferes with such a process.

This research gives another example of the known reactivity of foetal pancreas to various stimuli $[3,8,17$, $19,30,33,40]$.

\section{References}

1. Batts, A.: Use of the golgi apparatus as an indicator of level of activity of the cells of the islets of Langerhans. Ann. Acad. Sci. (N.Y.) 82, 302-318 (1959).

2. Best, C.H., Haist, R.E.: The effect of insulin administration on the insulin content of the pancreas. J. Physiol. 100, 142-146 (1941).

3. Bossart, H., Sistek, J., Chabot, V., Felber, J.P.: Surcharge glucosique et insulinémie chez le foetus et la mère sub partu. Schweiz. Med. Wschr. 99, 13501354 (1969).

4. Chu, P.C., Goodner, Ch.J.: Lack of functional suppression of pancreatic beta cells during chronic insulin replacement in the rat. Endocrinology, 82, 296-302 (1968).
5. Colwell, J.A., Furey, W.L.: Insulin secretion by insuloma and normal pancreas slices. Studies in a patient with multiple endocrine adenomata. Diabetes 17, $83-89(1968)$.

6. Debray, Ch., De La Tour, J., Vaille, Ch., Roze, C., Souchard, M.: Pancréas exocrine et modificateurs de la glycémie. II. Action de l'insuline seule et en présence d'eau bicarbonatée sodique sur la sécrétion pancréatique et biliaire chez le rat. Thérapie $\mathbf{2 4}, 283-$ 295 (1969).

7. Erlandsen, S.E., Wells, L.J., Lazarow, A.: Effects of beef insulin upon the granulation of beta cells in cultures of pancreases of fetal rats from diabetic mothers. Anat. Rec. 157, 415-423 (1967).

8. Espinosa De Los Monteros, A., Driscoll, S. G., Steinke, J.: Insulin release from isolated human foetal pancreatic islets. Science 168, 111- $1112(1970)$.

9. Frerichs, H., Reich, U., Creutzfeldt, W.: Insulinsekretion in vitro. I. Hemmung der glucoseinduzierten insulinabgabe durch insulin. Klin. Wschr. 43, 136$140(1965)$.

10. Gomez-Acebo, J., Parrilla, R., Candela, J.L.R. : Fine structure of the $A$ and $D$ cells of the rabbit endocrine pancreas in vivo and ineubated in vitro. I. Mechanism of secretion of the A cells. J. cell Biol. 36, 33-44 (1968).

11. Grodsky, G.M., Curry, D.L.: Insulin secretion from the perfused pancreas. Acta Diab. Latina 5, (suppl. 1), 140-161 (1968). Quoted by Iversen, J., Miles, D.W.: Evidence for a feed back inhibition of insulin on insulin secretion in the isolated perfused canine pancreas. Diabetes 20, 1-9 (1971).

12. Hahn, H. J., Michael, R. : Inhibition of insulin release by endogeneous insulin in vitro. Horm. Metab. Res. 2, 119 (1970).

13. Hahn, H.J., Michael, R. : Untersuchungen an Langerhansschen inseln in vitro. V. Die hemmung der glukoseinduzierten insulinsekretion durch endogenes insulin in vitro. Endokrinologie 57, 98-107 (1970).

14. Hausberger, F. X., Ramsay, A.J.: The influence of the administration of glucose, and of glucose together with insulin, respectively, on the granulation of beta cells in guinea pigs. Anat. Rec. 112, 341 (1952).

15. Hellman, B., Lernmark, A.: Evidence for an inhibitor of insulin release in the pancreatic islets. Diabetologia $5,22-24(1969)$.

16. Iversen, J., Miles, D.W.: Evidence for a feed back inbibition of insulin on insulin secretion in the isolated, perfused canine pancreas. Diabetes 20, 1-9 (1971).

17. Jacquot, R.: Some hormonally controlled events of liver differentiation in the perinatal period. In proceeding's of the conference on "Hormones in development" Nottingham, the National Foundation. September 1968, 587 - 599. Eds. Hamburgh M., Barrington, E.J.W. New York: Appleton Century Crofts 1971.

18. Kemmler, W., Steiner, D.F.: Conversion of proinsulin to insulin in a subcellular fraction from rat islets. Biochem. biophys. Res. Communications 41, $1223-$ $1230(1970)$.

19. Lambert, A.E., Jeanrenaud, B., Renold, A.E.: Enhancement by caffeine of glucagon-induced and tolbutamide-induced insulin release from isolated foetal pancreatic tissue. Lancet 1967 II, 819-820.

20. Latta, J.S., Harvey, H.T.: Changes in the islets of Langerhans of albino rat induced by insulin administration. Anat. Record 82, 281-295 (1942).

21. Lazarus, S.S., Shapiro, S., Volk, B.W.: Secretory granule formation and release in rabbit pancreatic A-cells. Diabetes 17, 152-160 (1968).

22. Levine, R.: Mechanisms of insulin secretion. New Engl. J. Med. 283, 522-526 (1970). 
23. Lin, T.M., Alphin, S.: Vagal secretory nerves for pancreatic secretion in the rat. Amer. J. Physiol. 197, $555-557(1959)$.

24. Logothetopoulos, J., Kraicer, J., Best, C. H. : Granulation and reactive zine in the cells of the islets of Langerhans. Effect of prolonged insulin treatment. Diabetes 10, 367-374 (1961).

25. Logothetopoulos, J., Kaneko, M., Wrenshall, G.A., Best, C.H.: Zinc, granulation and extractable insulin of islet cells following hyperglycemia or prolonged treatment with insulin. In: The symposium on the structure and metabolism of pancreatic islets, 333347. Eds. Brolin, S.E., Hellman, B., Knutson, H. Oxford: Pergamon Press 1964.

26. Logothetopoulos, J.: Electron microscopy of the pancreatic islets of rat. Effects of prolonged insulin injection. Diabetes 15, $823-829$ (1966)

27. Loubatières, A., Mariani, M.M., Chapal, J.: Inhibition. de la sécrétion d'insuline par l'élévation de la teneur en insuline du milieu irriguant les cellules B des îlots de Langerhans du pancréas. C.R. Acad. Sc. (Paris) 266, 2245-2247 (1968).

28. Malaisse, W.J., Malaisse-Lagae, F., Lacy, P.E., Wright, P.H.: Insulin socretion by isolated islets in presence of glucose, insulin and anti-insulin serum. Proc. Soc. exp. Biol. Med. 124, 497-500 (1967).

29. Malaisse, W.J., Malaisse-Lagae, F.: Chronic effects of insulin and glucagon upon islet function. Diabetologia $5,349-352(1969)$.

30. Milner, R.D.G.: The secretion of insulin from foetal and postnatal rabbit pancreas in vitro in response to various substances. J. Endocrinol. 44, 267-272 (1969).

31. Perrier, H.: Evolution de l'ultrastructure du pancréas chez le foetus de rat. Diabetologia 6, 605-615 (1970).

32. Picon, L., Montané, M.: Glycémies foetales et maternelle chez la ratte à divers stades de la gestation. Action de l'insuline injectée au foetus sur sa glycémie. C.R. Acad. Sc. (Paris) 267, 860-863 (1968).
33. Picon, L., Bailly, F., Kervran, A., Rieutort, M.: Hyperglycémie chez le foetus de rat injecté de sérum anti-insuline. C.R. Acad. Sc. (Paris) 271, 774-776 (1970).

34. Renold, A.E.: Insulin biosynthesis and secretion. A still unsettled topic. New Engl. J. Med. 282, 173$182(1970)$

35. Sodoyez, J.C., Sodoyez-Goffaux, F., Foa, P.P.: Evidence for an insulin-induced inhibition of insulin release by isolated islets of Langerhans. Proc. Soc. exp. Biol. Med. 130, 568-571 (1969).

36. Sodoyez, J.C., Sodoyez-Goffaux, F., Rossen, R.M., Foa, P.P.: Function of the pancreatic B-cells in hamsters bearing a transplantable islet cell tumor. Metabolism 18, 433-438 (1969).

37. Sodoyez, J.C., Sodoyez-Goffaux, F.: Sensibilité à l'insuline des cellules $B$ du pancréas de la souris obèse hyperglycémique. Ann. Endocr. 32, 199-202 (1971).

38. Sorenson, R.L., Steffes, M.W., Lindall, A.W.: Subcellular localization of proinsulin to insulin conversion in isolated rat islets. Endocr. 86, 88-96 (1970).

39. Vaille, Ch., Debray, Ch, De La Tour, J., Roze, C., Souchard, M.: L'insuline: accélérateur de la cholérèse et de la sécrétion pancréatique externe du rat. Ann. pharma. frane. 27, 333-342 (1969).

40. Vecchio, D., Luyckx, A., Zahnd, G.R., Renold, A.E.: Insulin release- induced by glucagon in organ cultures of fetal rat pancreas. Metabolism 15, 577-581 (1966).

H. Perrier et R. Jacquot Laboratoire de Physiologie animale et Centre de Biologie et Biochimie du Développement

Faculté des Sciences

B.P. No. 347

F-51-Reims

France 